\title{
Determining the suitability trends for settlement based on multi criteria in Kirkuk, Iraq
}

\author{
Najat Qader Omar and Aram Mohammed Raheem*
}

\begin{abstract}
Background: Swift population growth and unplanned settlement led to the phenomenon of informal urban in Iraqi cities because of warfare, political instability and economic blockage for more than three decades. Economic status and political migration to sensitive areas were mainly due to weak management of local government organizations. The complexity process in the growth trend for settlements does not involve any modern factors requirements such as topography, soil bearing capacity and other environmental factors issues that may result in a determination of settlement zone trends. Today, after the disaster, it has become necessary to determine the suitability trend for the new settlement area to determine which areas are compatible for the settlement area purpose.
\end{abstract}

Methods: This study focused on using multi factors data integrated with GIS and expert choice to employ and drive the weights associated with suitability determination of settlement trends.

Results: These tools would help to generate a synergistic effect to contribute efficiently in suitability, select trends and examine the concept of land suitability evaluation and its implementation possibility for settlements based on the bearing capacity of the soil and other multi factors.

Conclusions: The results of this study have shown that the social aspects represented as security, have a strong role in reshaping the city beside the spatial aspects, which could interest urban planners and decision makers.

Keywords: Geographic information system, Multi criteria decision analysis, Soil-bearing capacity, Multi factors, Settlement areas

\section{Background}

Growth in human population is one of the major causes of urbanization all over the world where more than half of the world population lives in urban areas and the population will further increase [38]. The recent UN population projection has also proven that the urban population will increase to $85 \%$ by 2030 . Therefore, it is expected that the urban population in 2050 would be 6.4 billion out of a total of 8.9 billion world population ([39] Revision). Migrating from the rural to urban areas is the main reason for the urban rapid. There is a more rapid increase in the poverty level in urban areas compared to the rural areas and this has caused an alteration in the spatial distribution of human settlements and changed

* Correspondence: engaram@yahoo.com

Civil Engineering Department, Engineering College, Kirkuk University, Kirkuk, Iraq the use of natural land to urban use. Based on recent studies, half of the world's population currently lives in the cities [15]. According to the United Nations [16], the growth of urban populations is the cause of the urban sprawl and spatial expansion in the city, which refers to the inadequate use of resources. With this trend, the major problem here is not to stop the rapid growth of urban areas but to initiate appropriate strategies, which can be used in the control and direction of urban expansion in terms of location and timing.

Rebuilding the settlement trends in the growth areas is highly associated with comfort and a sense of possibility of the planning in the future. In addition, housing facilities fostered by residents often fail to comply with the physical condition of the soil and the environment [4]. Therefore, it is necessary to evaluate the suitability of soil for the settlement area with the current environmental
Springer Open

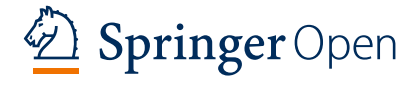

(c) The Author(s). 2016 Open Access This article is distributed under the terms of the Creative Commons Attribution 4.0 International License (http://creativecommons.org/licenses/by/4.0/), which permits unrestricted use, distribution, and reproduction in any medium, provided you give appropriate credit to the original author(s) and the source, provide a link to the Creative Commons license, and indicate if changes were made. 
conditions and balance the nature with the foundation of the structure. Soil suitability evaluation is an approach or a way to determine the potential of soil resources [17]. Meanwhile, soil suitability might be represented as the process to predict the potential use of soil based on their attributes [32]. The soil appropriateness result will provide some information or guideline for the sole use. It was stated that soil evaluation is also an integral part of soil use planning to ensure continuous soil management [27]. Soil use of the settlement zone should be harmonious with the soil supporting ability [23, 24].

Therefore, suggest that, from the planning point of view, the soil-bearing capacity is defined as the nature's ability to fully support the growth of the people, physical development and human resource exploration without destructing the nature. It was defined that soil-bearing capacity is the land capacity, which supports the physical structural weight and others $[26,35,36]$. However, it was added that allowable bearing capacity is the maximum weight of the soil resistance that can support the settlement's land use [8]. It is required to model the soil as spatial because of the influence of random heterogeneity of soil properties and their effect on the soil bearing capacity [29].

A multi-criteria decision analysis (MCDA) approach with a geographical information system (GIS) was used for land suitability [12]. GIS was utilized to obtain and screen unsuitable areas, while MCDA was used to select the most suitable sites. Both GIS and MCDA were developed to minimize the wasting of the space for the siting of hazardous waste landfills. Synergistic effect is generated by combining these tools, which contribute to the efficiency and quality of spatial analysis for industrial site selection. Ways have been demonstrated to integrate GIS with multicriteria methods and adapt MCDA for use in spatially continuous problems [14]. New opportunities have been provided to increase the accessibility of GIS-based MCDA and practitioners including web-based participation and advanced visualization of decision processes. Choosing an appropriate location for an activity or a facility is obviously related to decision support and MCDA. The problem can be generalized as a question of what must be done and where it should be realized [1].

In the context of the distinction between the site selection problems, the land suitability analysis considered as an important method. The explicit site search analysis determines some other special characteristics such as the land shape, contiguity, compactness by aggregates beside the site suitability all according to the used factors [22].

One of the most useful applications of GIS for planning and management is the land-use suitability mapping and analysis $[5,24]$. Broadly defined, land use suitability analysis aims to identify the most appropriate spatial pattern of future land uses according to specific requirements, preferences, or predictors of some activities [5]. Most GIS has been developed with theories of spatial representation and computing.

Land-use suitability analysis is more than a GIS-based procedure, even if it involves participatory approaches. While databases and spatial information systems are important components of planning activities, planners deal with constituencies, power relationships, and complex urban and regional problems. This called socio-political perspectives on the use of GIS as a tool for planning [22]. GISs are used to integrate with other systems and methods such as systems for decision-making (DSS) and multi-criteria decision-making (MCDM). Combining these tools generate a homogeneous effect contribute to obtain an efficient spatial analysis for selecting planning and development areas [31].

The most significant factors that describe decision problems or affect the choice and implementation of MCDA methods are the number of decision makers, number of objectives, number of alternatives, existence of constraints and risk tolerance [31]. There are a large number of multi-criteria decision methods that are in use in GIS environment. The most commonly used analyses are: Analytic Hierarchy Process (AHP), Weighted Linear Combination (WLC), Ordered Weighted Averaging (OWA), ELECTRE, PROMETHEE, VIKOR and MultipleObjective Land Allocation (MOLA) [37].

AHP is a theory of measurement through pairwise comparisons and relies on the judgments of experts to derive priority scales [33]. It is one of the more popular methods of MCDM. In AHP, the result of pairwise comparisons and criteria weights is obtained by a generated matrix. Consistency ratio (CR) is used to determine the decisions in pairwise comparison. $\mathrm{CR}$ reveals the random probability of values being obtained in a pairwise comparison matrix. The number of the criteria determines the specific comparison and the procedures follows AHP performs [36]. A mathematical method called pairwise comparisons method in the context of the Analytical Hierarchy Process (AHP) was developed [33]. In this method, ratio matrix comparisons were created. As an input, it takes the pairwise comparisons of the parameters and produces their relative weight as an output [1]. Kirkuk city has experienced significant shortages in planning with very little growth. Since the Iraqi-Iranian War in 1980s and the First Gulf War in 1991, followed by the international sanctions, investment in new infrastructure and planning development were prevented. Hence, the deterioration in planning conditions in many Iraqi cities and especially in Kirkuk city has been neglected led to the growing phenomenon of slums with poor public services and basic infrastructure of sewerage and streets. Also, garbage problems have been increased significantly $[5,7,16,18,21]$.

Kirkuk city lies in the northern part of Iraq and its soil has shown a wide variation in the degree of development. 
Soil development increases from the southern to the northern part of Kirkuk city due to the differences in the activity of soil formation factors such as parent materials, recent alluvium, calcareous or gypsiferous and climatic conditions ranging from dry to sub humid with mean annual precipitation of less or more than $100 \mathrm{~mm}$ in the northern region of Iraq. Physiography in Kirkuk city ranges from the Mountain in the northern to nearly flat plain in the southern part with low density of natural vegetation [3]. The main objective of this study is to focus on the multi-criteria especially soil bearing capacity and how to adopt the GIS method for such implementation. To ensure that the application can be implemented, a geospatial analysis compiled with the variable soil bearing capacity that can be observed and measured in the terms of settlement zone is used.

\section{Methods}

\section{Study area}

Kirkuk city is one of the Iraq's ancient governorates that is inhabited by different ethnicities and characterized by a rich culture and a distinguished history. It has a heritage of about 5000 years and its cultural heritage should be certainly protected and enhanced. Kirkuk is the fourth rank among Iraqi cities (formerly known as Tameem). It is located on latitude $35^{\circ} 28^{\prime} 5^{\prime \prime}$ north and longitude $44^{\circ} 23^{\prime} 31^{\prime \prime}$ east, and about $350 \mathrm{~m}$ above the sea level under UTM reference project zone $38 \mathrm{~N}$ with an area of about $9,679 \mathrm{~km}^{2}$ [28]. Kirkuk city's area represents $2.2 \%$ of the total area of Iraq $[6,28]$. It includes 13 administrative units forming four districts. These districts are Kirkuk, Daquq, Al-Hawiga and Maxmur where Kirkuk district has an area of $797 \mathrm{~km}^{2}$ as shown in Fig. 1 . In 2010, the population of Kirkuk was estimated to be $1,475,711$ people compared to 753,171 inhabitants in
1997 and constituted an increase of $3.4 \%$ of the people in Iraq $[28,39]$.

\section{Dataset}

The dataset in the paper is mainly divided into three parts: primary part, which is collection and digitizing thematic maps and layers, the second part includes decision making process were carried out with 25 professional decision makers and assigned score weight and the third part applies the analysis using ArcGIS and Expert choice software. The flow chart for the procedures of land suitability zone selection is shown in Fig. 2.

Many factors influence settlement area and urban development including environmental, physical and socioeconomic as well as political issues. The steps taken in this analysis began with collecting data that are necessary to meet all the criteria. The selected criteria were obtained from the literatures, interview with field experts and planning guidelines in Kirkuk city to evaluate the best location for the settlement area to support decisions about the location for additional housing and urban development.

Several factors closely associated with the best location for the settlement area such as distance from built up area, topographic (slope), distance from river, soil (bearing capacity), distance from road, and land use activities.

\section{Built up area}

The study area includes 14 districts. According to the role of the type of municipalities, Kirkuk city lies within the grade $\mathrm{A}$. The area around the city (boundary of master plan) for $7 \mathrm{~km}$ is the area for expansion. Buffering the master plan to obtain the boundary of the study area is shown in Fig. 3a. For Kirkuk population, Food Ration Office (FRO) reports that the number of individuals

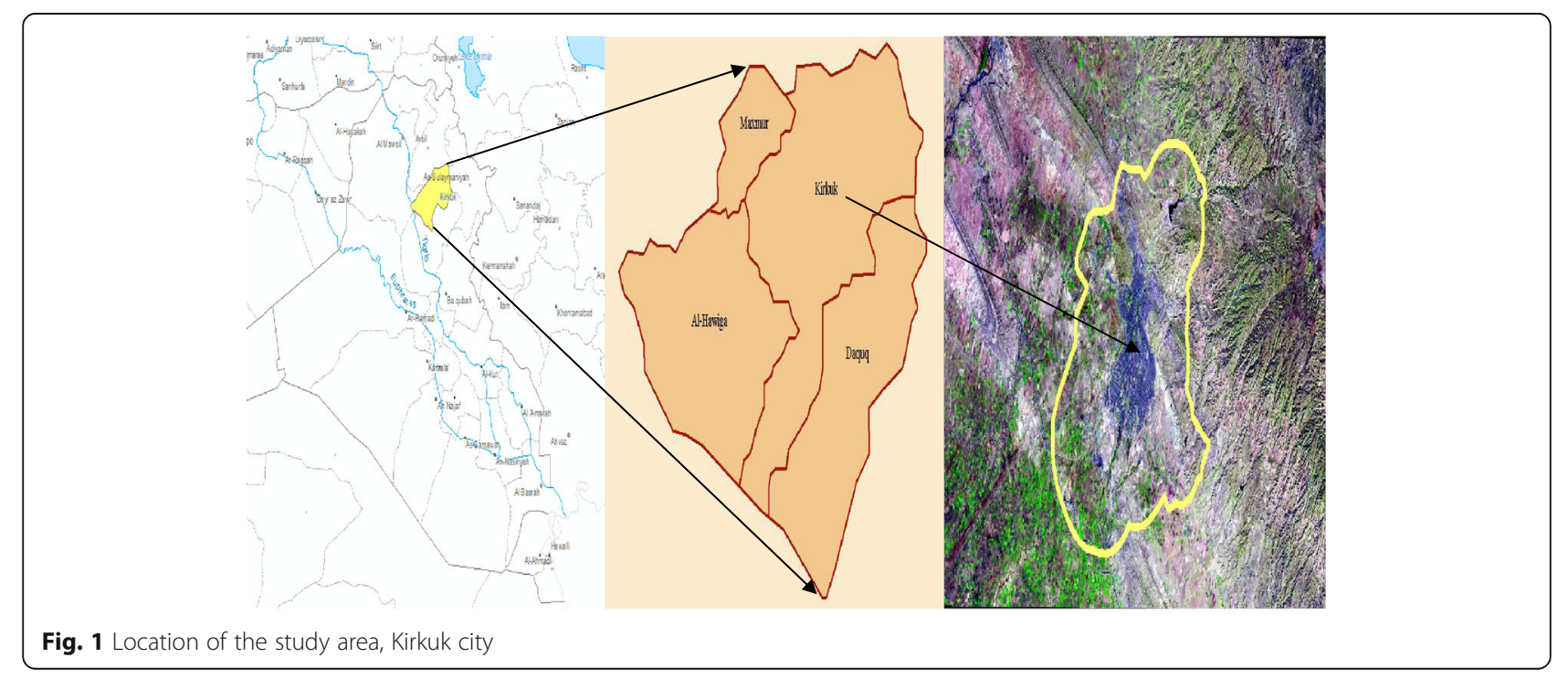




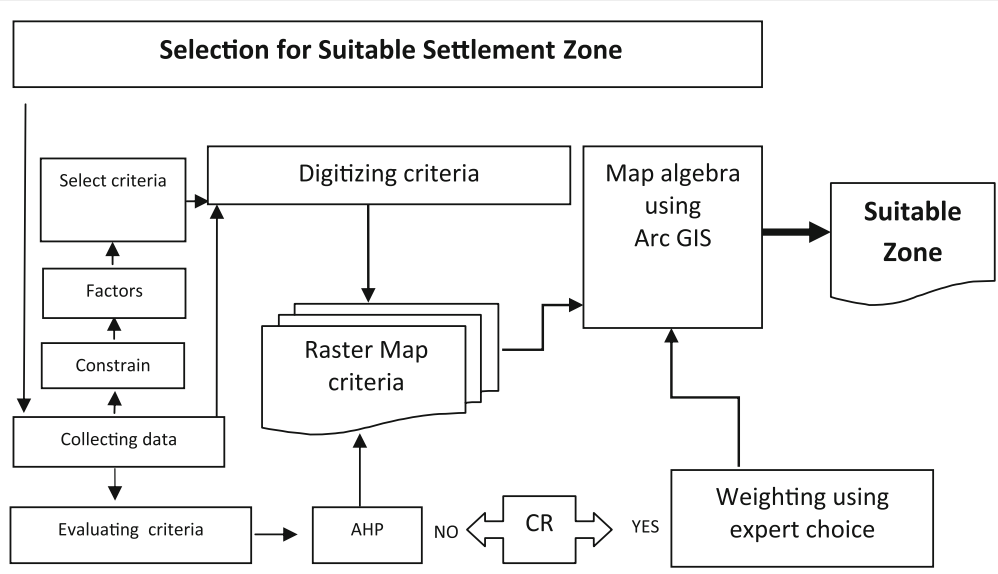

Fig. 2 Flow chart of the method of suitability zone selection
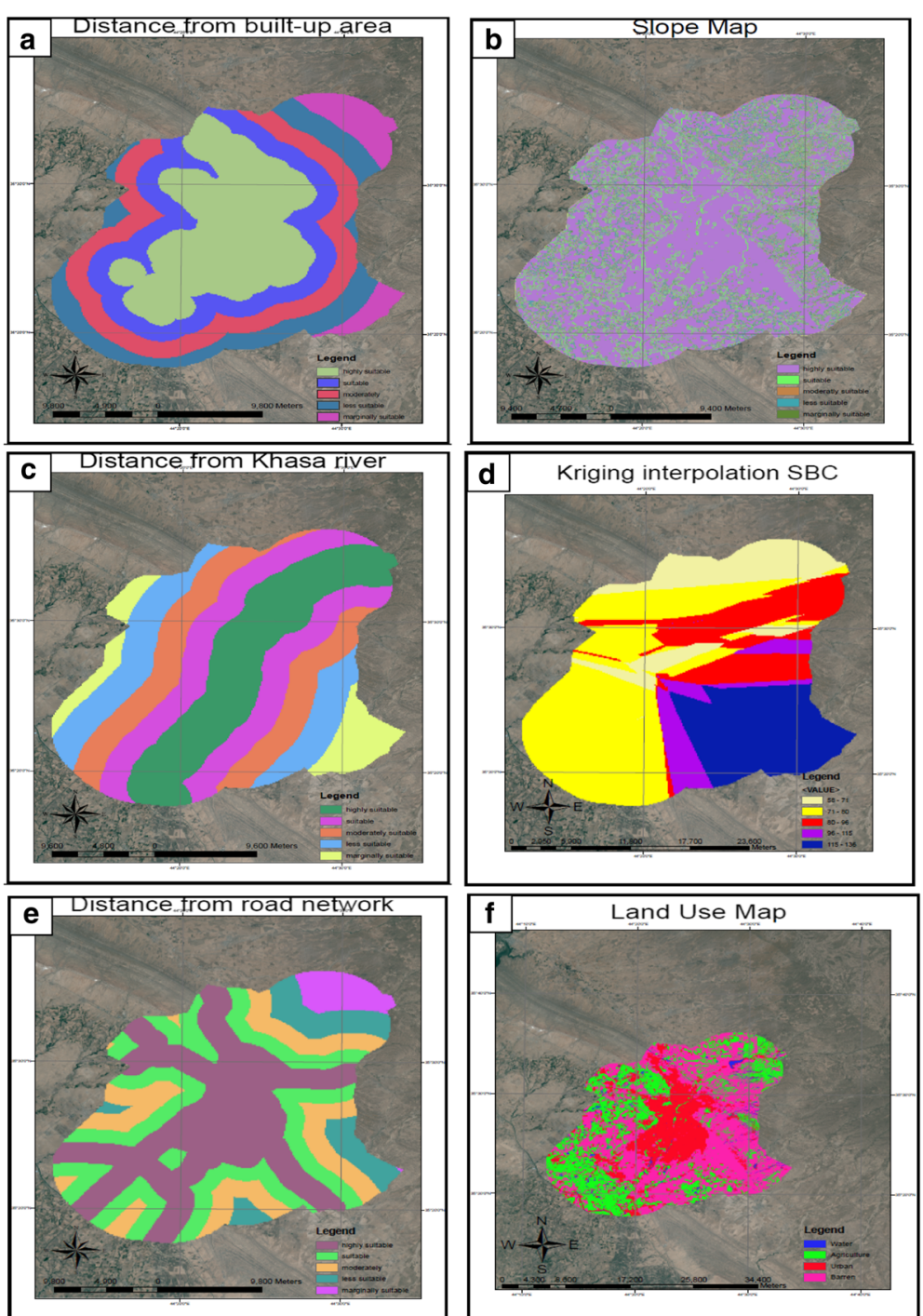

Fig. 3 The suitability map of Kirkuk city based on a built-up area, $\mathbf{b}$ topographic, $\mathbf{c}$ Khasa river, $\mathbf{d}$ field soil bearing capacity, e road network, and $\mathbf{f}$ land use map 
registered to receive food in the province is $1,149,129$. While the Kirkuk ID Card Office (KICO) reports the population as $1,353,700$. Thus, it is not possible to derive a form of population growth from that origin, but it can be only used to assist the settle of the total population in the country. An average of the two sources would run a population for the province of approximately 1,250,000. Thus, an average estimate of $1,250,000$ is adopted as an assumption in this work [28].

\section{Topographic}

The slope is one of the factors that affects the direction of planning and associated with topography. For instance, based on the master plan policies, the sites on or near cliffs is not suitable for urban growth development and the high elevation area should be avoided because the cost of planning in these areas is very high. Hence, areas with slopes that exceed $10 \%$ are usually not suitable for residential development [1]. However, the morphology of the land around Kirkuk varies from the north to the south. The city is bounded by undulating mountains from the north, northeast and practically to the east, forming the morphology of the land. The west and south is more or less flat forming a terrain, which starts from northeast to southwest. The development of Kirkuk city has limited extent towards the northern part of the city and most of the city development has concentrated towards the southern part along the bank of Khasa river. Man-made obstacles have influenced the city expansion although the main trends of development dictated by the natural axis of the topography. The suitability of the land of Kirkuk city based on slope factor has been shown in Fig. 3b.

\section{Khasa Chia River}

Khasa is a winter borne river that runs through Kirkuk city in the northern part of Iraq. It dries up entirely in the summer but turns into a raging river in the winter. The Khasa river may flood during any winter season as happened in the 1950s. The river has a symbolic value to the city's inhabitants and it is one of the tributary streams of the Tigris River. The suitability of the land of Kirkuk city based on distance from Khasa Chia river has been shown in Fig. 3c.

\section{Soil bearing capacity}

A direct field-testing has been used to determine the soil resistance for the land of Kirkuk city using cone penetration test [34]. The work mostly concentrated on the spatial analysis of the cone penetration test values and land suitability evaluation models of Food and Agriculture Organization of the United Nations (FAO) adjusted for settlements [9-11]. The GIS is used in managing spatial data and presenting visual classification for the results.
The suitability of the land of Kirkuk city based on measured bearing capacity has been shown in Fig. 3d.

\section{Road network}

There are six main roads leading to Kirkuk where five of them are primary roads. These roads are from Mosul (North-West), Erbil (North), Suleymaniyeh (East), Tikrit and Samarra (South-West), Baghdad (South), and Laylan (South -Eastern) as shown in Fig. 3e. For the most part, the primary roads are dual carriageway and appear to be in a reasonable condition [28].

\section{Land use map}

The land use map for Kirkuk city is shown in Fig. 3f. The city center can be considered as an urban area with $25 \%$ of the land. Up to $40 \%$ of the land of the city is barren. The agricultural area is distributed with different percentages in the northern, western and southern parts of the city with $8 \%$ of water in the whole city.

\section{Model discription \\ Weighting criteria, pair wise comparison matrix and consistency}

Multi-Criteria Evaluation (MCE) and Analysis Hierarchy Process (AHP) technique employed to obtain information of the main criterion factors in this work. Weightings' obtained from the process of the hierarchical comparison is influenced by applying factors. Weighting gained from experts' interviews carried out with 22 different expert professions such as town planner, architects, engineers, environmental scientist and social urban planner by giving a particular criterion factors. The consultations with the experts have been done depending on questionnaires AHP matrix. Every evaluation has been performed using nine factors selected after discussion with experts using the most influential factors on urban development and residential site selection and the next step is done by calculating weighs for each criterion. Factors divided into two types.

Firstly, spatial factors were represented by built up, road, river, and ESA (environmental sensitive area). Secondly, social factors were characterized by income, protection area, same ethnic area, population density and topography factor. To obtain an analysis of the sensitivity of the weightings, nine separate pair wise comparison for main factors were made for each preference factor. Matrix for factors in both social and spatial made to reflect the preference towards a certain factors is shown in Table 1.

Pair wise comparison methods were used in generating the weights of the criteria depending on the relative importance of the criteria evaluation, which represents the stakeholders' preferences. The factors were compared with each other via pair wise comparison matrix that measures the relative preference among the urban 
Table 1 Geometric means and normalized weights

\begin{tabular}{lcl}
\hline Factors & GEO Mean & Normal Geo Mean \\
\hline Distance from built up area & 0.13101 & 0.131112799 \\
Topographic (slope) & 0.22058 & 0.221888104 \\
Distance from river & 0.22256 & 0.271644145 \\
Soil (bearing capacity) & 0.21413 & 0.260068852 \\
Distance from road & 0.10088 & 0.1003861 \\
Land use & 0.10033 & 0.01490000 \\
Sum & 0.98949 & 1 \\
\hline
\end{tabular}

growth factors. The values of the comparisons are specified using the range of weights from 1 to 9 and 1 to $1 / 9$ in the principal of AHP scales. An evaluation of the weights is conducted to specify alternatives and compute the related absolute numbers. The relative importance of the factors through AHP pair wise scale matrix was accomplished using Expert Choice Decision software for different field experts.

The relative weights, which indicate the importance of the factors, are represented in the perspectives of experts. The pair-wise comparison matrix is done by Expert Choice software derives the priority weight for this study. The relative weights of the nine factors will be the input parameters for Arc GIS spatial analysis work in determining the development suitability maps. Depending on the AHP method [33], consistency ratio (CR) should be checked in the second stage of the analysis to verify the reliability of the judgment of the decision makers and the $C R$ should be $\leq 0.1$. This ratio indicated the reasonable level of consistency in the comparison. Because of the CR, each comparison matrix for the experts was adjusted until acceptable consistency is achieved. The preference in the land development according to the factors gain weights by calculating the mean value passing the consistency ratio and expressed by an equation. Expert choice software used to calculate the weighing factor matrices for 22 experts within the city in deferent field regarding urban planning and housing. Each factor gains specific value. A geometric mean was used to calculate the average of all values.

The Euclidean distance calculated to the geographical features for spatial factors (distance from built up, road, river, ESA), while the inverse weight distance used to calculate the distance for social factors (population density, land value and security area and same ethnic) using ARCMAP 10 environment. Expert evaluation values were averaged accordingly. Topography factor (slope) is obtained by DEM in degree for 2013. Some urban development influence factors should be considered. Therefore, identifying the possible urban developments, which influence factors, are very important in order to interpret this development process. Based on the literature review and opinions of expert decision makers, there are several significant causal criterions (factors and constraints) affecting the urban patterns. Some possible urban development influencing factors for Kirkuk urban development process from 2013 were identified as population density, topography, proximity to build up area, same ethnic area, proximity to security area, distance from network road, distance availability, usability of Khasa river and land value for social and economic activities. The geometric mean (GM) of 22 decision makers was initially determined. As used in Table 1, normalization is the weight of each factor divided by the total of the factors' weights.

\section{GIS model}

In geographic information system (GIS), spatial analysis that support map algebra could produce intrinsic suitability maps based on the weighing of the criterion from AHP and expert choice software. Each of the input themes is assigned with an influence weight based on its importance. The results are multiplying and overlying all raster combing all factors and constrains in terms of the weights. This process is often used in site selection and land suitability of an area when there are several factors affected the site $[2,3]$.

$$
\begin{aligned}
& \text { Suitability Map }= \\
& \qquad \Sigma\left[\text { factor map }\left(\mathrm{C}_{\mathrm{N}}\right) * \operatorname{weight}\left(\mathrm{W}_{\mathrm{N}}\right) * \operatorname{constraint}\left(\mathrm{b}_{0 / 1}\right)\right]
\end{aligned}
$$

Where $\mathrm{C}_{\mathrm{N}}=$ standardized raster cell,

$\mathrm{W}_{\mathrm{N}}=$ weight derived from AHP pairwise, comparison, and

$\mathrm{b}_{0 / 1}=$ Boolean map with values 0 or 1 .

The GIS model would apply Multi-Criteria Evaluation (MCE) and Analysis Hierarchy Process (AHP) technique to get different weights from the studied aspects to determine the best settlement area and best growing direction in Kirkuk city.

\section{Results and Discussion}

\section{Spatial analysis of soil bearing capacity}

The resulting analysis of the soil bearing capacity using Meyerhof formula [25] is being used. To predict the overall land surface, the GIS is used with the interpolation concept. Spatial classification based on the field soil bearing capacity values is used in applying this function. In summary, interpolation is the process of changing the data points into the area. Inverse distance weighted, natural neighbor, spline, and kriging trend are the rules used in the interpolation. Furthermore, Booth and Mitchell [2, 3]; Gorr and Kurland [13] and Pramono [30] have confirmed that Kriging rules has the advantages of unbiased properties, minimum variance, and it 
serves as a linear combination rather than observation. Kriging interpolation results from the data analysis of the soil bearing capacity in Kirkuk city is presented in Fig. 4. Based on the bearing capacity evaluation, the best and worst settlement areas lie in southern west and southern east parts of Kirkuk city respectively.

\section{Road accessibility cost aspect}

Road accessibility is one of the important parameters for urban development since it provides linkage between the settlements. The distance to an existing urban area is crucial because it significantly affects moving costs. Hence, the roads are an important factor in housing development because their presence represents human activity. The road locations must be adjacent to build up areas (existing neighborhood) in the low-density population areas within one to five $\mathrm{km}$ from the main and secondary roads [40]. Based on the road accessibility evaluation, the best and worst settlement areas lie in central and northern east parts of Kirkuk city respectively.

\section{Khasa river safety aspect}

The risks of Khasa river can arise from flooding in the rainwater season weather. In addition, the location must be far by at least one $\mathrm{km}$ far from the military camps and the pollution sources represented by oil and gas companies. The map of suitability distance of Kirkuk city

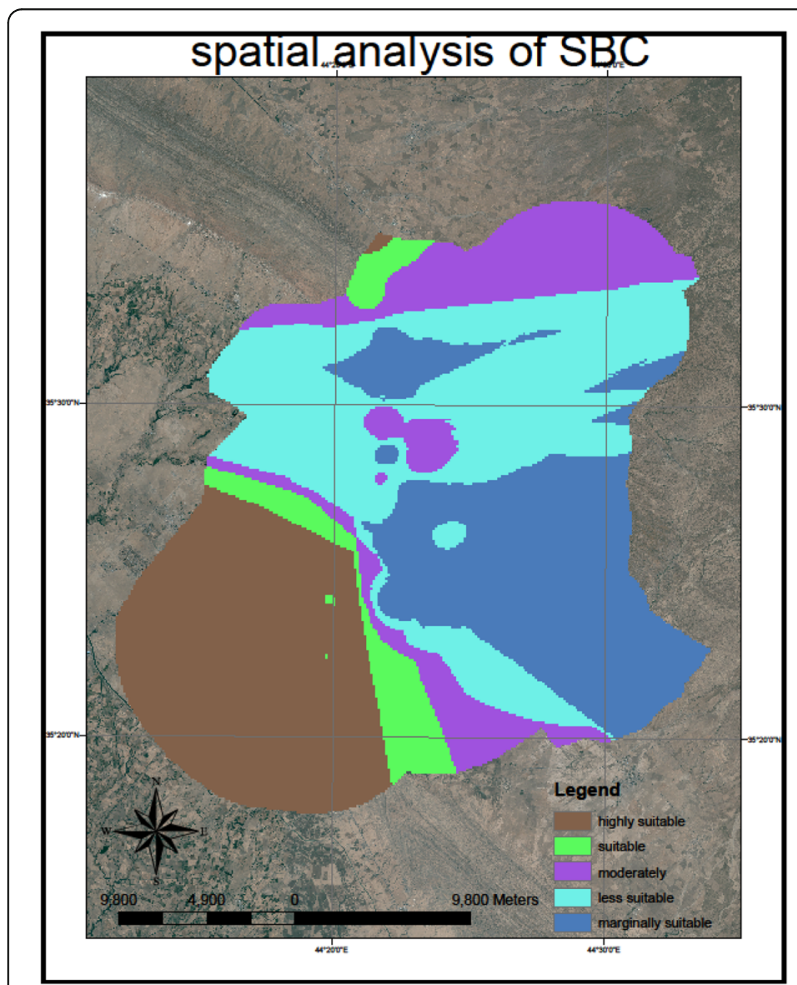

Fig. 4 The suitability map of Kirkuk city based on spatial analysis of soil bearing capacity from Khasa river has been shown in Fig. 3c. For safeguarding natural areas, no building sites are allowed within the ground water basin. In addition, any building or projects are prohibited to be built within oil and gas companies areas. The locations must be far by at least three $\mathrm{km}$ from the airport. The exclusion zones might be based on the noise from the airport operation, areas affected by aircraft landing pattern, and areas that would interfere with airport radar [20]. Housing area should be far by at least three and five $\mathrm{km}$ from industries and waste treatment station areas respectively. Based on the Khasa river safety evaluation, the best settlement area lies in the central part of Kirkuk city. Nevertheless, the worst settlement area lies in the southern east and central west parts of Kirkuk city.

\section{Land evaluation suitability for settlement}

Soil strength can be determined by its soil bearing capacity. The relationship between the strength and the conus pressure is proportionate, where the soil is harder when the conus value on the CPT measurement is higher $[35,36]$. The bearing capacity-land consistency can be identified in Table 2 .

The land suitability evaluation system has been adopted by the FAO. Suitability categories have been adopted to represent the class. Order $\mathrm{S}$ corresponds with class where $\mathrm{S}_{1}$ (highly suitable), $\mathrm{S}_{2}$ (moderately suitable) and $\mathrm{S}_{3}$ (marginally suitable). Order $\mathrm{N}$ does not comply with Class where $\mathrm{N}_{1}$ (currently not suitable) and $\mathrm{N}_{2}$ (permanently not suitable). The ground consistency, which became thematic settlement eligibility criteria, is in line with the literature review analysis [23, 24]. With this concept of matching, a map of interpolation that has been shown in Fig. $3 \mathrm{~d}$ is reclassified based on the class suitability criteria. The distribution maps of soil bearing capacity provide preliminary information on the carrying capacity of the land.

\section{Kirkuk city suitability using GIS}

High resolution aerial image up to $0.1 \mathrm{~m}$ was obtained from the municipality of Kirkuk city and used for georeferencing. Most spatial databases of various thematic maps of the study area including the main master plan in 1984 were drawn by hand. Layers were created by

Table $\mathbf{2}$ Land consistency based on cpt values

\begin{tabular}{ll}
\hline Land consistency & Soil Bearing capacity $\left(\mathrm{kN} / \mathrm{m}^{2}\right)$ \\
\hline Very soft & $58-71$ \\
Soft & $71-80$ \\
Medium & $80-96$ \\
Hard & $96-115$ \\
Very hard & $115-136$ \\
Extra hard & $>136$ \\
\hline
\end{tabular}


digitizing vectors using GIS software (ARCMAP 9.2). All features were derived from the aerial image compared with the master plan such as the road network, built up areas, river, as well as ESA (environmentally sensitive area) created for a specific time. Landsat image-7 download from United State Geographic Survey official website (USGS) "http://www.usgs.gov/" with $30 \mathrm{~m}$ spatial resolution is adequate to capture the features characteristic scale of human development. Shuttle Radar Topography Mission (SRTM) provides Digital Elevation Image (DEM) and it was a part of one arc second $(30 \mathrm{~m})$ that has been used to obtain the slope of the city "http://glcf.umd.edu/data/ $\mathrm{srtm} /$ ". A comparison between old master plan, master plan zoning, proposed master plan using GIS, and expansion direction based on 1975 master plan is shown in Fig. 5.

In order to compare the outcome of the suitability map with an existing master plan (hard copy), the city shape and urban is growing towards the north and east in general. However, the zoning of the master plan is growing towards the south. These details has been obtained according to the report of the master plan prepared by [19] associated with international-consultants and development and astics as shown in Fig. 5.

It seems from previous studies that the best direction for the expansion in Kirkuk city is the western and southern direction according to the spatial factors. Despite of Kirkuk master plan, a proposal developed by Pell Frischmann consultancy for USA Iraq Transition
Assistance Office did not gain any attraction by number of KPC (Kirkuk Province Council) for a number of political reasons [6]. The suitable sites according to the results were allocated in undesirable sites and nonpermissible zones for residential development in comparison with the last master plan. In addition, the master plan was limited by the characteristic undulating mountain formation from the north and east sides. Based on the overall evaluation of GIS model, the best settlement areas lies in the central part of Kirkuk city. However, the worst settlement part lies along the eastern part and few distributed areas along the western part of Kirkuk city.

\section{Conclusion}

Multi criteria decision-making represented by AHP technique was used in this study to evaluate the multi factors including spatial and non-spatial analysis, affected the suitability settlement trends selection analysis integrated with GIS as a tool. Final map has shown the suitability location for residential development that could significantly influence the benefit of having less investment. The system has been tested and the final map has been compared with the previous master plan. The results of this study illustrate that the social factors have an influence in the direction of the urban expansion and the site selection for housing might represent the greatest role in reshaping the city. Based on the results of this study, the best direction for Kirkuk city is growing

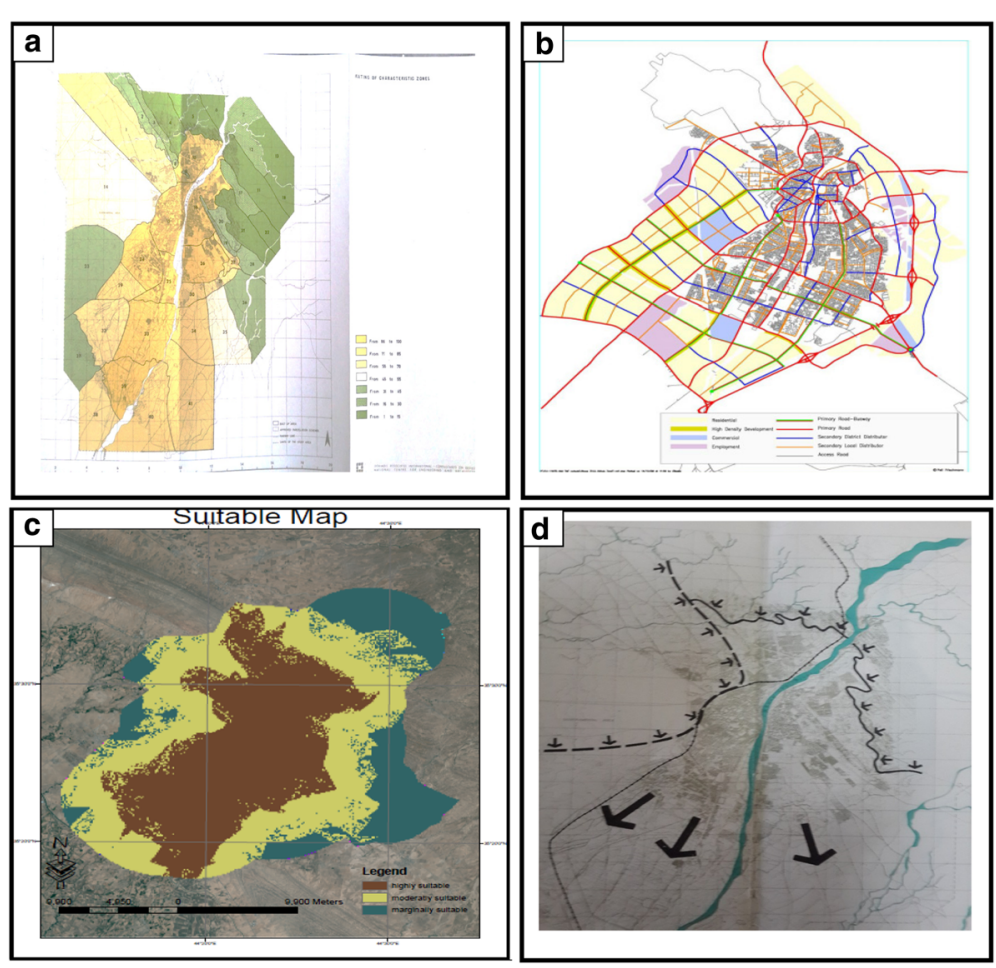

Fig. 5 a Kirkuk Master Plan [20], b Master Plan Zoning, c Proposed Master Plan Using GIS, and d Expansion Direction According to Master Plan of 1975 
towards the north and east ignoring the slope and oil companies limitation as well as the cost required for repairing the lands. On the other hand, the result has provided a technique to the assistance decision makers to examine the priority steps for the housing projects.

The results of this study indicate that the spatial factor such as soil bearing capacity of Kirkuk land as a whole is in the order of S (fit). Based on the suitability class, half of Kirkuk area lies in $S_{3}$ class (marginally suitable) and the rest lies in $S_{1}$ (highly suitable) and $S_{2}$ (moderately suitable) classes. In details, the percentages of suitability classes were $27 \%$ the $S_{1}$ area, $18 \%$ in $S_{2}$ area, and $55 \%$ in $\mathrm{S}_{3}$ area. This indicates that the soil bearing capacity in all areas of Kirkuk city can well support basic settlement (maximum of 3 floors). This, however, does not apply to higher buildings. Furthermore, this study can be used as a base for the settlement planning.

\section{Authors' contributions}

Multi criteria method is implemented with GIS technique for the first time to study the settlement in Kirkuk city. All authors read and approved the final manuscript.

\section{Competing interests}

The authors declare that they have no competing interests.

Received: 22 June 2016 Accepted: 6 September 2016

Published online: 12 December 2016

\section{References}

1. Al-Shalabi MA, Mansor SB, Ahmed NB, Shiriff R. GIS based multicriteria approaches to housing site suitability assessment. Munich: XXIII FIG Congress. Shaping the Change; 2006. p. 1-17.

2. Booth B, Mitchell A. Getting started with ARCGIS. Redlands: (ESRI) Environmental System Research Institute, Inc; 2001.

3. Buringh P. Soils and soil conditions of Iraq. Baghdad: Ministry of Agriculture, Agricultural Research and Projects; 1960

4. Chiara JD, Koppelman L. Urban planning and design criteria, 2nd ed. University of Minnesota. Van Nostrand Reinhold Company; 1975.

5. Collins C, Wolff S. Creating political space to resolve intercommunal tensions in Kirkuk Iraq. 2008. p. 1-6. Report available http://www.stefanwolff. com/files/Kirkuk_Case Study.pdf.

6. Eisenstadt M, Knights M, Ali A. Iran's influence in Iraq countering Tehran's whole-of-government approach. 2011. Policy Focus \#111, The Washington Institute for Near East Policy.

7. Eldefrawi S. Impact of physical structure of informal settlements on the social integration of residents. Berlin: International RC21 Conference; 2013. p. 1-11.

8. Erizal. Modul Kuliah Daya Dukung Tanah (Bearing Capacity). Bogor: Institut Pertanian Bogor; 2013.

9. FAO. A framework for land evaluation FAO. 32nd ed. Rome: FAO (Food and Agriculture Organization); 1976.

10. FAO. Guidelines: Land evaluation for rainfed agriculture. FAO Soils Bull. 1983;52:1-16.

11. FAO. Land evaluation towards a revised framework. Rome: FAO (Food and Agriculture Organization); 2007

12. Feo DG, Gisi DS. Using MCDA and GIS for hazardous waste landfill siting considering landscarcity for waste disposal. Waste Manag J. 2014;34:2225-38.

13. Gorr WL, Kurland KS. GIS tutorial. Redlands: Environmental System Research Institute (ESRI) Press; 2008.

14. Greene R, Devillers R, Luther JE, Eddy BG. GIS-based multiple-criteria decision analysis. Geogr Compass. 2011;5(6):412-32.

15. Habitat, U.N. Planning sustainable cities: Global report on human settlements. Nairobi: UN Habitat; 2009

16. Habitat, U.N. The state of arab cities 2012 challenges of urban transition. Nairobi: UN Habitat; 2012.
17. Hardjowigeno S, Widiatmaka. Evaluasi Kesesuaian Lahan dan Perencanaan Tataguna Lahan. Yogyakarta: Penerbit Universitas Gajah Mada (UGM Press); 2007. p. 352.

18. Hill A, Lindner C. Modelling informal urban growth under rapid urbanisation - ACA-based land use simulation model for the city of Dares Salaam, Tanzania. Doctoral thesis, TU Dortmund University. 2010. Available at https://eldorado.tu-dortmund.de/handle/2003/27283.

19. International Doxiadis. Kirkuk master plan report. Kirkuk Province: Kirkuk Provincial Government; 1975

20. Jeffery S, Estes J. Geographic information systems an introduction. Englewood Cliffs: Prentice Hall; 1990.

21. Kirkuk Provincial Government Report. 2007. Kirkuk Province. Available at http://www.ncciraq.org/images/infobygov/NCCI_Kirkuk Governorate_Profile.pdf.

22. Malczewski J. GIS-based land-use suitability analysis: a critical overview. Prog Plan. 2004:62(1):3-65.

23. Masri RM. Analisis Keruangan Kesesuaian Lahan untuk Permukiman di Kabupaten Bandung dan Bandung Barat. Forum Geografi. 2012;26(2):190-201.

24. McHarg IL. Design with nature. Garden City: Published for the American Museum of Natural History by the Natural History Press; 1969.

25. Meyerhof GG. Some recent research on the bearing capacity of foundations. Can Geotech J. 1963;1(1):16-26.

26. Muchtar A. Modul Kuliah Rekayasa Pondasi. Indonesia: Universitas Narotama; 2011.

27. Niekerk AV. A comparison of land unit delineation techniques for land evaluation in the Western Cape, South Africa. Land Use Policy. 2010;27(3):937-45.

28. Omar NQ, Ahamad MS, Hussin WMA, Samat N, Ahmed SZB. Markov CA, multi regression, and multiple decision making for modeling historical changes in Kirkuk city, Iraq. J Indian Soc Remote Sensing. 2014;42(1):165-78.

29. Popescu R, Deodatis G, Nobahar A. Effects of random heterogeneity of soil properties on bearing capacity. Probabilistic Eng Mechanics. 2005;20(4):324-41.

30. Pramono GH. Akurasi Metode Idw dan Kriging Untuk Interpolasi Sebaran Sedimen Tersuspensi. Jurnal Forum Geografi. 2008;22(1):97-110.

31. Rikalovic A, Cosic I, Lazarevic D. GIS based multi-criteria analysis for industrial site selection. Procedia Engineering. 2014;69:1054-63. Available at: http://dx.doi.org/10.1016/j.proeng.2014.03.090.

32. Rossiter DG. A theoretical framework for land evaluation. Geoderma. 1996;72(3-4):165-90.

33. Saaty TL. Decision making with the analytic hierarchy process. Int J Serv Sci. 2008;1(1):83.

34. Schmertmann JH. Guidelines for cone penetration test: performance and design. Washington, DC: Federal Highway Administration Dept. of Transportation; 1978.

35. Singh B, Prakash S. Soil mechanics and foundation engineering. India: Nem Chand \& Bros; 1990

36. Uyan M. GIS-based solar farms site selection using analytic hierarchy process(AHP) in Karapinar region, Konya/Turkey. Renew Sust Energ Rev. 2013;28:11-7.

37. Velasquez M, Hester PT. An analysis of multi-criteria decision making methods. Int J Oper Res. 2013;10(2):56-66.

38. Weber C, Puissant A. Urbanization pressure and modeling of urban growth: example of the Tunis Metropolitan area. Remote Sens Environ. 2003;86(3):341-52

39. World Urbanization Prospects. 2012. http://esa.un.org/unpd/wup/.

40. Yeh AG, Li X. Sustainable land development model for rapid growth areas using GIS. Geography Info Sci. 1998;12(1):169-89.

\section{Submit your manuscript to a SpringerOpen ${ }^{0}$ journal and benefit from:}

- Convenient online submission

- Rigorous peer review

- Immediate publication on acceptance

- Open access: articles freely available online

- High visibility within the field

- Retaining the copyright to your article

Submit your next manuscript at springeropen.com 